Research letter

\title{
Effect of the needles with different nanostructured carbon coatings on the osteoporotic bone tissue in the experiment
}

\author{
Alexandra Yu. Burmatova
}

Ural State Medical University, Yekaterinburg, Russia

Received 16 November 2017, Revised 11 October 2018, Accepted 17 October 2018

(C) 2017, Burmatova A.Yu.

(C) 2017, Russian Open Medical Journal

\begin{abstract}
The article presents the comparative analysis of osseointegrative properties of different nanostructured carbon (a-C and $\mathrm{CN}_{0.25}$ ) coatings of the needles which is based on a study of regulating bone remodeling growth factors as well as a marker of apoptosis and bone resorption TNF-related apoptosis-inducing ligand (TRAIL).

Material and Methods - The experiment was performed on 64 male rats of the Wistar line. Animals were immobilized by resection of the hind limb bones in proximal part of the right calf in order to simulate immobilization osteoporosis (IOP). Needles with carbon nanostructured $\mathrm{CN}_{0.25}$-coatings were implanted for the rats of the first group (32 rats), needles with diamond-like nanostructured a-C were implanted for the rats of the second group (32 rats). On $30^{\text {th }}, 60^{\text {th }}$ and $90^{\text {th }}$ day after implantation we determined the concentrations of bone morphogenetic protein 2 (BMP-2), transforming growth factor beta (TGF-ß), TRAIL and the bone matrix resorption marker RatLaps in rats serum by ELISA.

Results - The level of osteogenic growth factors concentrations was higher in group with a-C-coatings in comparison to that in group with $\mathrm{CN}_{0.25}$-coated needles (BMP-2 on the $90^{\text {th }}$ day, TGF- $\beta 1$ on the $60^{\text {th }}$ and $90^{\text {th }}$ days), probably because of more pronounced cells and intercellular matrix elements adhesion to a-C-coatings. $\mathrm{CN}_{0.25}$-coatings demonstrated more pronounced activation of the bone resorption factor: TRAIL - a marker of apoptosis and a cytokine that promotes the activation of resorptive cells osteoclasts was higher in all observed periods.

Conclusion - Thus, the results of the study indicated that effect of nanostructured a-C and $\mathrm{CN}_{0.25}$ coatings with various surface topography and chemical composition on the process of bone remodeling was different.
\end{abstract}

Keywords: nanostructured coatings of needles, immobilization osteoporosis, BMP-2, TGF-ß, TRAIL.

Cite as Burmatova AYu. Effect of the needles with different nanostructured carbon coatings on the osteoporotic bone tissue in the experiment. Russian Open Medical Journal 2019; 8: e0110.

Correspondence to Alexandra Yu. Burmatova. Address: Gromova str., 30, Yekaterinburg, 620146, Russia. E-mail: alex.burmatova@mail.ru. Mob.: $+79505467200$

\section{Introduction}

Hypokinesia is a stress factor for the body. In the absence of mechanical loading, the gravity vector of bone tissue changes, which has effect on bone remodeling $[1,2]$.

Already on the $30^{\text {th }}$ day of immobilization the experiment showed changes in the metabolic activity of osteogenic cells, on the $90^{\text {th }}$ day of immobilization osteoporotic changes of bone tissue were noted $[3,4]$.

The most effective method for patients' treatment with fractures and non-unions under immobilization osteoporosis (IOP) is transosseous osteosynthesis by G.A. Ilizarov (TOS) [5-7]. However, when standard metal fixators from medical steel were used, already on the 14 days after implantation an increase of dystrophic and sclerotic changes in the near-spine region of bone tissue were noted. These changes led to micro-mobility of the fixators $[8,9]$. Therefore, it is important to search for the methods of improvement the osseointegrative properties of the fixators used for the TOS.
Currently, carbon nanostructured coatings of metal fixators, which possess osteoinductive properties, are actively investigated and applied in traumatology [10-12]. The research on the bone defects replacement with titanium implants covered by nanostructured coatings revealed a different effect of a-C and $\mathrm{CN}_{0.25}$-coatings, which vary in chemical composition, surface topography and the method of application, on the activity of osteogenic cells [13].

It is of interest to analyze the regulating bone tissue regeneration mechanisms in implantation of needles with a-C and $\mathrm{CN}_{0.25}$-coatings. Regeneration of bone tissue is a complex process. It is important role of growth factors and cytokines because they coordinate intercellular interactions, effect the differentiation, proliferation, and activity of bone cells [14].

Aim of study: comparing the dynamics of growth factors and cytokines, regulating bone tissue remodeling during implantation of needles with nanostructured carbon diamond-like a-C-coatings and carbon $\mathrm{CN}_{0.25}$-coatings, ligated by nitrogen atoms. 


\section{Material and Methods}

Characteristics and methods of obtaining needles with nanostructured coatings

The author's development and manufacture of needles for experimental studies on animals was carried out by the employees of the Laboratory of Carbon Nanomaterials of MN Mikheev Institute of Metal Physics of the Ural Branch of the Russian Academy of Sciences (Yekaterinburg, Russia). Original nanostructured coatings (diamond-like a-C-membrane and composite $\mathrm{CN}_{0.25}$-membrane, doped with nitrogen atoms) were applied on the needles made of $12 \times 18$ H9T steel with a given roughness and surface thickness. Coatings differ in chemical composition, electrical conductivity, number of sp3-bonds, surface structure. Membranes were deposited by the vacuum-plasma method in the UVNIIPA-04 vacuum machine.

\section{Materials}

The experiment was carried out on 64 male Wistar rats at the age of 3 months weighing 120-150 g. The conditions for handling, handling and withdrawal of animals were in accordance with the Council Directive of 24 November 1986 "On the approximation of laws, regulations and administrative provisions of EU member states on the protection of animals used for experimental and other scientific purposes".

\section{Design}

Immobilization osteoporosis was modeled by amputation of the shin bones of the right hindlimb at in the proximal part (the idea of the IOP model on dogs is Professor SV Gyulnazarova's, 1985, revision of the model in rats by PhD A.Y. Kuchiev, 2008). The surgeries on animals were performed by PhD A.A. Ganzha.

On the $90^{\text {th }}$ day of immobilization (by the moment of the formation of osteoporotic changes in bone tissue), the distal metaphysis of the right femoral and the proximal metaphysis of the right tibia were implanted with needles made of $12 \mathrm{X} 18 \mathrm{H} 9 \mathrm{~T}$ steel with nanocarbon coatings deposited on them. The needles with $\mathrm{CN}_{0.25}$-coatings were implanted to animals of the $1^{\text {st }}$ group (32 rats); needles with a-C-coating to animals of the $2^{\text {nd }}$ group (32 rats). The ends of the needles were processed and immersed in soft tissues. All operations and removal of animals from the experiment were performed under intramuscular anesthesia Xyla Vet $0.05-0.10 \mathrm{ml} / \mathrm{kg}+$ Zoletil $1-2 \mathrm{mg} / \mathrm{kg}$. To compare the effect of the coatings on bone remodeling the concentration of key osteogenesis activators - bone morphogenetic protein 2 (BMP-2), Transforming growth factor beta (TGF- $ß$ ) as well as markers of bone resorption - TNF-related apoptosis-inducing ligand (TRAIL), bone-related degradation products from C-terminal telopeptides of type I collagen in rat (RatLaps) was determined on the $30^{\text {th }}, 60^{\text {th }}$ and $90^{\text {th }}$ day after implantation.

\section{Methods}

Determination of the concentrations of the examined parameters was carried out in the blood serum of animals by enzyme immunoassay according to the protocols attached to the kits using controls. We used sets for measure BMP-2, TRAIL of Cloud-Clone Corp. (USA); TGF-ß1 of eBioscience (USA); RatLaps of Immunodiagnosticsystems (Great Britain). Organism species: Rattus norvegicus (Rat). The research was carried out on a Stat Fax 3200 analyzer (Awareness Technology, Inc., USA) in combination with Stat Fax 2600 microplate washer (Medica, USA) and ELMI shaker (ELMI Ltd, Latvia).

Comparison of the groups was performed using the MannWhitney test for independent samples. The choice of the criterion is conditioned by the small sample power and the abnormal distribution of the indices (the normality of the distributions was estimated using the Pearson's chi-squared test $\chi 2$ ). The results are presented as median with lower and upper quartiles - Me (LQ, $\mathrm{UQ)}$.

\section{Results}

The dynamics of BMP-2 concentration in the blood serum of animals with various nanostructured coatings appeared to be multidirectional (Table 1 ). In the group with $\mathrm{CN}_{0.25}$-coatings (group 1) the concentration of BMP-2 has decreased to the $60^{\text {th }}$ and to the $90^{\text {th }}$ days, while in the group with the a-C-coatings (group 2) it has increased. On the $90^{\text {th }}$ day in the group with a-Ccoatings, the level of BMP-2 was significantly higher than in the group with $\mathrm{CN}_{0.25}$-coatings in 3 times.

The level of TGF-ß1 turned out to be significantly higher in the group with a-C-coatings: on the $60^{\text {th }}$ and $90^{\text {th }}$ days in 1.6 times (Table 2). It's peak concentrations in the group with $\mathrm{CN}_{0.25}$ coatings were observed by the $30^{\text {th }}$ day. By the $60^{\text {th }}$ day the level of TGF-ß1 has decreased in 1.9 times.

The positive dynamics of TRAIL was observed in the first group (with $\mathrm{CN}_{0.25}$-coatings) by the $90^{\text {th }}$ day (Table 3 ). In the group with a-C-coatings, no such dynamics were observed. At all times of observation, the TRAIL level was higher in the group with $\mathrm{CN}_{0.25}$ coatings: on the $30^{\text {th }}$ day in 1.5 times, on the $60^{\text {th }}$ day in 1.9 times, on the $90^{\text {th }}$ day -5 -fold.

Also, in analysing the data, a significant negative correlation between the TRAIL level and the bone matrix resorption marker (RatLaps) in the group with a-C-coatings of the needles was found. The Spearman correlation coefficient was -0.552 ( $p=0.009)$. Correlation between TRAIL and RatLaps in the group with $\mathrm{CN}_{0.25}$ coatings was not obtained.

\section{Discussion}

Transforming growth factor beta family plays an important role in reparative regeneration and bone tissue formation. Of these, BMP-2 and TGF- $\beta 1$ are the key regulators of osteogenesis: they stimulate the differentiation and proliferation of mesenchymal stem cells into osteoblasts [15]. Therefore, higher concentration values of these growth factors in the $1^{\text {st }}$ group probably reflect a more pronounced osteoinductive effect of a-Ccoatings compared to $\mathrm{CN}_{0.25}$-coatings.

It is known that BMP-2 stimulates the synthesis of collagen type I, forming the bone matrix, by osteoblasts [16]. In connection with that, the BMP-2 dynamics obtained in the group with a-Ccoatings consists the data provided previously (in the group with aC-coating, the values of the concentration of type I collagen propeptides that are Collagen type I synthesis markers were higher at all terms after implantation) [17].

A crucial role in the bone remodeling regulation plays the TRAIL (apoptosis-inducing ligand). It is known that TRAIL can cause a programmed death of osteoblasts, interacting with death receptors DR4 and DR5 [18]. Therefore, the higher values of TRAIL in the group with $\mathrm{CN}_{0.25}$-coatings may indicate more pronounced activity of osteoblasts apoptosis in this group. 
Table 1. Dynamics of BMP-2 concentration in serum of animals, $\mathrm{ng} / \mathrm{m}$

\begin{tabular}{|c|c|c|c|}
\hline Groups & $30^{\text {th }}$ day after implantation & $60^{\text {th }}$ day after implantation & $90^{\text {th }}$ day after implantation \\
\hline $1^{\text {st }}$ group & $553.90(482.90,625.03)$ & $406.80(323.80,557.00)$ & $285.90(251.61,366.79)^{*^{+}}$ \\
\hline $2^{\text {nd }}$ group & $455.30(381.15,589.43)$ & $522.30(225.80,543.48)$ & $856.60(771.87,1082.48)$ \\
\hline
\end{tabular}

operation. The results are presented as $M e(L Q, U Q)$.

Table 2. Dynamics of TGF-ß1 concentration in blood serum of animals, $\mathrm{ng} / \mathrm{ml}$

\begin{tabular}{|c|c|c|c|}
\hline Groups & $30^{\text {th }}$ day after implantation & $60^{\text {th }}$ day after implantation & $90^{\text {th }}$ day after implantation \\
\hline $1^{\text {st }}$ group & $36.04(32.47,39.41)$ & $18.50(17.26,19.74)$ & $20(17.17,23.91)$ \\
\hline $2^{\text {nd }}$ group & $21.82(18.57,35.26)$ & $29.44(23.45,35.69)^{*}$ & $31.73(27.13,36.32)^{*}$ \\
\hline
\end{tabular}

* - statistically significant difference $(p \leq 0.01)$ in relation to the $1^{\text {st }}$ group. The results are presented as Me (LQ, UQ).

Table 3. Dynamics of TRAIL concentration in serum of animals, $\mathrm{ng} / \mathrm{ml}$

\begin{tabular}{|c|c|c|c|}
\hline Group & $30^{\text {th }}$ day after implantation & $60^{\text {th }}$ day after implantation & $90^{\text {th }}$ day after implantation \\
\hline $1^{\text {st }}$ group & $1.82(1.78,1,83)^{*}$ & $1.77(1.42,1.98)^{*}$ & $2.15(1.89,2.25)^{*}$ \\
\hline $2^{\text {nd }}$ group & $1.25(1.02,1.41)$ & $0.91(0.86,0.93)$ & $0.37(0,32,1.10)$ \\
\hline
\end{tabular}

Moreover, TRAIL promotes bone resorption, also under a low bone mineral density. It is known that along with receptors of apoptosis, TRAIL can bind one of the main inhibitors of osteoclastogenesis - osteoprotegerin (OPG). It was also shown that in conditions of weightlessness, the enhancement of osteoclastogenesis is TRAIL-mediated [19, 20]. Thus, the significant negative correlation of the marker of bone resorption RatLaps and TRAIL obtained in the $2^{\text {nd }}$ group (with a-C-coatings) (increase in the RatLaps concentration was accompanied by a decrease in the TRAIL level) suggests that when implanting needles with a-Ccoatings TRAIL suppresses RANK-RANKL-mediated (RANK, receptor activator of nuclear factor kappa-B; RANKL, receptor activator of nuclear factor kappa-B ligand) osteoclastogenesis in the condition of osteoporosis, possibly through inhibition of phosphorylation of mitogen-activated protein kinase (MAPK) [21]

The results on the more significant osteoinductive properties of a-C-coatings in comparison with $\mathrm{CN}_{0.25}$-coatings are consistent with previous studies. In the experiment on the replacement of bone defects with titanium implants with nanostructured $\mathrm{a}-\mathrm{C}$ and $\mathrm{CN}_{0.25}$-coatings applied on them, their various effects on the activity of osteogenic cells were revealed. Morphological data and values of concentrations of regulatory molecules indicated the best properties of a-C-coatings [22].

Previously performed morphological researches of bone tissue when implanting spokes with nanostructured carbon coatings in osteoporotic bone of rats revealed a significant decrease in the diameter of the spinal canal and a decrease in the thickness of the fibrous capsule when using a-C coatings compared to $\mathrm{CN}_{0.25}$ coatings [23], which also is consistent with the results of this study.

\section{Conclusion}

The obtained results show differences in the influence of the needles with nanostructured (a-C and $\mathrm{CN}_{0.25}$ ) coatings with surface-differentiated topography and various chemical composition on the process of bone tissue remodeling. Thus, a-Ccoatings, probably due to better adhesion to them of cells and elements of the intercellular matrix than to $\mathrm{CN}_{0.25}$-coatings, contributed to a more pronounced activation of osteogenic factors
(BMP-2 and TGF-b) and less pronounced degree activation of the bone tissue resorption factor (TRAIL).

Conflict of interests: none declared.

Ethical approval

All applicable international, national, and institutional guidelines for the care and use of animals were followed.

\section{References}

1. Oganov VS, Bogomolov VV. Human bone system in microgravity: review of research data, hypotheses and predictability of [the bone system] state in extended (exploration) missions. Aerospace and Environmental Medicine 2009; 43(1): 3-12. Russian. https://elibrary.ru/item.asp?id=20231019.

2. Bauman WA, Cardozo CP. Osteoporosis in individuals with spinal cord $\begin{array}{lllll}\text { injury. } \quad P M & R & 2015 ; & 7(2): & 188-201\end{array}$ https://dx.doi.org/10.1016/j.pmrj.2014.08.948.

3. Kuchiev AYu. Application of a hyperbaric oxygenation at treatment of nearthroses of the tubular bones complicated by osteoporosis (experimental clinical trial). PhD dissertation. Novosibirsk, Russia, 2008; 106 p. Russian. https://elibrary.ru/item.asp?id=16166043.

4. Trifonova EB. The value of metabolic processes in formation of Immobilization-induced osteoporosis. Fundamental Research 2011; (6): 177-181. Russian. https://elibrary.ru/item.asp?id=16216595.

5. Gyulnazarova SV. Immobilization osteoporosis: pathogenesis and the principles of bone non-union treatment in view of that. Review of literature and our own data. Vestnik Travmatologii i Ortopedii im VD Chaklina 2010; (2): 5-12. Russian. https://elibrary.ru/item.asp?id=17696979.

6. Chattopadhyay P, Mandal P, Sabui KK, Banka PK. Treatment of difficult non-union of long bones using the Ilizarov technique. Int J Sci Stud 2017; 4(12): 27-30. https://dx.doi.org/10.17354/ijss/2017/90.

7. Sahu RL, Ranjan R. Treatment of complex nonunion of the shaft of the tibia using llizarov technique and its functional outcome. Niger Med $\mathrm{J}$ 2016; 57(2): 129-133. https://dx.doi.org/10.4103/0300-1652.182076.

8. Gyulnazarova SV, Kudryavtseva IP, Ganzha AA. Morphostructural bone changes in using metallofixators on background of immobilize osteoporosis. Fundamental research 2014; 7(3): 468-472. Russian. https://elibrary.ru/item.asp?id=21736800.

9. Guerado E, Caso E. Challenges of bone tissue engineering in orthopaedic patients. World J Orthop 2017; 8(2): 87-98. https://dx.doi.org/10.5312/wjo.v8.i2.87. 
10. Catledge SA, Thomas V, Vohra YK. Nanostructured diamond coatings for orthopaedic applications. Woodhead Publ Ser Biomater 2013; 2013: 105-150. https://dx.doi.org/10.1533/9780857093516.2.105

11. Makarova EB, Zakharov YuM, Rubshtein AP, Isaikin Al. Integration of bone tissue to porous titanium implants with diamond-like nanocoatings. Genij Ortopedii 2011; 4: 111-116. Russian. https://elibrary.ru/item.asp?id=17586396.

12. Bioengineering applications of carbon nanostructures. A. Jorio, ed. Springer International Publishing, Switzerland, 2016; 163 p. https://dx.doi.org/10.1007/978-3-319-25907-9

13. Makarova EB, Safonova GD, Rubshtein AP. Effect of different diamondlike coatings on the function of osteogenic cells in vivo. Vestnik Travmatologii i Ortopedii im VD Chaklina 2013; 7(1-2): 84-88. Russian. https://elibrary.ru/item.asp?id=20349989.

14. Principles of bone regeneration. J.J. Sela, I.A. Bab, eds. Springer, Boston, USA, 2012; 156 p. https://dx.doi.org/10.1007/978-1-46142059-0.

15. Chen G, Deng C, Li Y-P. TGF- $\beta$ and BMP signaling in osteoblast differentiation and bone formation. Int J Biol 2012; 8(2): 272-288. https://dx.doi.org/10.7150/ijbs.2929.

16. Radomisli TE, Moore DC, Barrach HJ. Weight-bearing alters the expression of collagen types I and II, BMP 2/4 and osteocalcin in the early stages of distraction osteogenesis. J Orthop Res 2001; 19(6): 1049-1056. https://dx.doi.org/10.1016/S0736-0266(01)00044-4.

17. Burmatova AY, Trifonova EB, Meshchaninov VN. Dynamics of bone resorption markers upon implantation nanostructured coated needles in osteoporotic rebuild bone. Journal of Ural Medical Academic Science 2016; 3(58): 33-38. Russian. https://elibrary.ru/item.asp?id=27448352

18. Mori G, Brunetti G, Colucci S, Ciccolella F, Coricciati M, Pignataro P, et al. Alteration of activity and survival of osteoblasts obtained from human periodontitis patients: role of TRAIL. J Biol Regul Homeost Agents 2007; 21(3-4): 105-114. https://www.ncbi.nlm.nih.gov/pubmed/18261262.

19. Vitovski S, Phillips JS, Sayers J, Croucher PI. Investigating the interaction between osteoprotegerin and receptor activator of NFkappaB or tumor necrosis factor-related apoptosis-inducing ligand: evidence for a pivotal role for osteoprotegerin in regulating two distinct pathways. J Biol Chem 2007; 282(43): 31601-31609. https://dx.doi.org/10.1074/ibc.M706078200.

20. Sambandam Y, Baird KL, Stroebel M, Kowal E, Balasubramanian S, Reddy SV. Microgravity Induction of TRAIL expression in preosteoclast cells enhances osteoclast differentiation. Sci Rep 2016; 6: 25143. https://dx.doi.org/10.1038/srep25143.

21. Zauli G, Rimondi E, Nicolin V, Melloni E, Celeghini C, Secchiero P. TNFrelated apoptosis-inducing ligand (TRAIL) blocks osteoclastic differentiation induced by RANKL plus M-CSF. Blood 2004; 104(7): 2044-2050. https://dx.doi.org/10.1182/blood-2004-03-1196.

22. Ganzha AA. Application of transverse osteosynthesis of spokes and rods with nanostructured carbon coatings in conditions of osteoporosis (experimental and clinical study). PhD dissertation thesis. Perm, Russia, 2016; 24 p. Russian. https://elibrary.ru/item.asp?id=30439334.

23. Makarova EB. Experimental substantiation of bone tissue defects replacement with porous titanium implants with carbon - containing non-resorable nanocoatings. DSc dissertation thesis. Ekaterinburg, Russia, 2015; 48 p. Russian. https://elibrary.ru/item.asp?id=30431512.

Authors:

Alexandra Yu. Burmatova - PhD student, Biochemistry chair, Ural State Medical University, Yekaterinburg, Russia. http://orcid.org/0000-00024511-7021. 